\title{
CONTRIBUTIONS TO A POST-COLONIAL ROMAN ARCHAEOLOGY: LINKING BRAZIL AND BRITAIN
}

\author{
Richard Hingley ${ }^{1}$
}

\section{Intertwined connections}

This paper reviews my collaborations with Professor Funari in order to provide a personal focus upon the significant contribution that he has made to the field of theory and historical archaeology. The focus of my contribution is upon the Roman period, which forms one part of Funari's wide range of interests. My paper is based in particular on the connections that Funari and I have developed since 1999. My first contact with Funari was when I contributed an article to a volume that he coedited with Martin Hall and Sîn Jones, Historical Archaeology: Back from the Edge (Funari, Hall and Jones eds 1999). This volume derived from a conference session held at World Archaeology Congress 3 in New Delhi (India) in 1994. Unfortunately I had been unable to attend, although Sîn Jones asked me to contribute an article to the publication. My article outlined some critical approaches to Roman Britain that aimed to re-focus study away from the elite and military populations of the province (Hingley 1999). It built upon the arguments that had already been outlined in my book, Rural Settlement in Roman Britain (Hingley, 1989).

It was in 1999 that I first became fully aware of Funari's wide academic interest and also of his contributions to Roman archaeological studies. My recollection is that we first met in 1999 at World Archaeology Congress 4 in Cape Town (South Africa). I was taking at the Congress about the 'clearance landscapes' of the Highland and Island of Scotland (Hingley, 2000a). My research on Scottish clearance landscapes aimed to prioritise the archaeological remains of the dispossessed communities that were cleared off their land to make way for sheep farming; many of these people were forced to emigrate to America and Australia. In early 1999 I was working as an Inspector of Ancient Monuments for Historic Scotland, the state heritage service. Heritage provision in Scotland had prioritised the tangible remains of Roman forts and frontiers, medieval castles and religious houses. Clearance landscapes appeared to me to

\footnotetext{
1 Associate Professor, University of Durham, Durham, United Kingdom. E-mail: richard.hingley@durham.ac.uk
} 
offer an alternative narrative that addressed the disposed. The main emphasis of my research, however, focused on the Roman period.

In the autumn of 1999 I move on to a post as Lecturer in Roman Archaeology at Durham University (England). My contact with Funari increased as a result, particularly after the publication of my book, Roman Officers and English Gentlemen (2000b). This explored the colonial origins of Roman archaeology in Britain, addressing the research of ancient historical and archaeologists during the late nineteenth and early twentieth centuries. I also edited a separate volume that contained a collection of papers entitled Images of Rome (2001); these articles addressed how the Roman imperial past had been drawn upon in various European countries and in the USA (Hingley ed., 2001). Funari noticed these works and I think that he could see their relevance in the context of the post-colonial approaches that he was seeking to promote for Brazilian archaeology. He arranged for the paper that I had published in the Images of Rome volume to be translated into Brazilian Portuguese and this was published in textos Didáticos Number 47 (Hingley, 2002). This volume also included an article by Jean-Pierre Vernant titled 'Fronteiras do Mito' and an introduction by Ranata Senna Garraffoni. ${ }^{2}$ I remember being very flattered to think that my article on the uses of 'Images or Rome' in England was of relevance to archaeologists in Brazil and this helped to encourage me to continue my post-colonial research.

Our initial discussions had indicated that Funari and I had many interests in common and we organised a session,'Colonialism and Identity: Origins and Otherness', at the World Archaeology Congress 5, at Washington in 2003. This was a very substantial and lively session and I particularly remember the discussions of origin myths and colonialism. I was deeply grateful that Funari found the time to help to organise and to contribute to this session since I realised at the Congress how busy he was with his commitments to the World Archaeology movement. Looking through the list of session's contributors, I have noticed the name of one of Funari's graduate students, Renato Pinto, who I was to meet again in Brazil. Funari and I discussed publishing the results off this lively session, although we were both too busy to pursue this idea.

These contacts with Funari helped develop my interests in post-colonial theory and Roman imperialism. The three successive sessions that I contributed to at World Archaeological Congress enabled me to communicate the arguments that I had been developing to a far broader

2 Textos Didáticos 47 was re-published in an expanded version in 2005. 
audience than my colleagues and friends in the developing post-colonial archaeology movement in Europe. I was particularly drawn to Funari's academic work because of his background in Roman archaeology, including his $\mathrm{PhD}$ research on Roman amphorae (Funari, 1996), but also more particularly because of his wide interests in historical archaeology, imperialism, colonialism and heritage - interests that we share.

As my research has developed, I have rather lost contact with the World Archaeology Congress but the three to which I contributed enabled me to extend my international contacts and also to set the research that I was undertaking in a broader theoretical context. In 2007 Funari asked me to write an article for an edited volume, New Perspectives on the Ancient World, that he was producing with two colleagues (Funair, Garraffoni and Latalien eds, 2008). This volume addresses 'Modern Perceptions and Ancient Representations' and again I was delighted to contribute a paper since the historical reception of Roman culture and imperialism are topics that have formed the core for my research since the late 1990s. This volume provides an international perspective on the ways that the classical past has been drawn upon across the world. Although Funari has such a wide range of articles and books that address a whole variety of issues in the politics of historical archaeology, this volume also helps to highlight his significant contribution to the archaeology of the Roman period. Together with other edited volumes that Funari has produced (Funari, Jones and Hall eds, 1999; Funari, Zarankin and Stovel eds, 2005), it also clearly illustrate his wide network of colleagues, international collaborators and graduate students.

My academic career at Durham University has enabled me to develop the research on Roman archaeology through the pursuit of a post-colonial and historiographical perspective and in 2005 I had published Globalizing Roman Culture (Hingley, 2005). My contacts with Funari and his exstudents remained very important as my research developed. I was deeply honoured when Funari invited me to visit to Brazil for a two-week lecturing tour during August 2008. This involved a series of lectures in Campinas and also a single lecture in Curitiba, where I was hosted by Renata Garraffoni. My partner and intellectual muse, Christina Unwin, was able to travel with me and we had such an excellent time with Funari and his research students. This was a tremendous social occasion for Christina and myself, as well as a highly-stimulating event. I remember the lively academic discussions and what I found most directly interesting was the living relevance of archaeology to many of the people that I spoke to in Brazil. This stems, I think, from the emphasis of much of the research that Funari and his students have been pursuing on the topic 
of heritage and the living relevance of the Roman past. Heritage brings us directly into contact with the contemporary relevance of archaeology. In the intellectual tradition of Roman archaeology scholars have tended to emphasise a distancing perception, which sidelines the political and cultural context in which ideas are generated and consumed - this is an agenda that I have seemed to challenge in my research (Hingley 2015a). To me the deepest relevance of the post-colonial and heritage research that has developed in Brazil is this focusing on the contemporary relevance of archaeological research. My visit to Brazil had a deep impacted upon my academic research.

In the early 2000s I was already beginning to re-focus to address the contemporary relevant of the Roman past. My initial agenda had concentrated rather more on the critique of the theory of Romanization (Hingley, 2000b; Hingley, 2001). During the late 1990s and early years of the new millennium a number of archaeologists in England, including David Mattingly and Jane Webster, were involved in a deep critique of this theory of Romanization and my research formed part of this postcolonial movement. The paper that Funari published in textos Didáticos 47 addressed this topic-looking at the use of the Roman past in the context of Victorian and Edwardian society in Britain. My interests were, however, shifting and Globalizing Roman Culture (2005) used post-colonial theory to explore how the Roman Empire was being re-created in the contemporary world, a topic that has continued to fascinate me (Hingley, 2015a). My lectures in Campinas and Curitiba in 2008 pursued this agenda by exploring the political context behind contemporary theories of Roman identity and cultural change. I was also able in Brazil to outline my early research on the afterlife of Hadrian's Wall, Britain's major Roman monument; I subsequently published this research in Hadrian's Wall: A Life (Hingley, 2012).

Funari and his colleagues published a collection of my papers translated into Brazilian Portuguese as a result of my visit (Hingley, 2010). These articles included translations of papers that I had published in 1991, 1996 and 2008. These were accompanied by an Introduction on theory and Roman studies in Brazil by Renata Garraffoni, Pedro Funari and Renato Pinto. I returned to Brazil briefly in 2009 to talk at a literary festival and again I was delighted to receive the invitation from Funari. I regret that I have been unable to visit Brazil more recently, largely as a result of competing commitments.

In 2013 Funari and I contributed separate papers to a session organised by Craig Cipolla and Katherine Hayes at the Society for Historical Archaeology meeting in Leicester (UK). This session was subsequently 
published as a volume titled Rethinking Colonialism (Cipolla and Hayes eds, 2015). Funari's paper, which he wrote jointly with Lúcio Menezes Ferreira links ancient and modern slavery (Ferreira and Funari, 2005). My paper explored the idea of identifying 'Descent Communities' in the study of Roman Britain (Hingley, 2015b). I had drifted somewhat away from the field of historical archaeology in the previous five years but the discussions at this lively session drew my attention back to the potential of cross-cultural and cross-temporal comparison. My paper for the edited volume enabled me to outline a new initiative that I was planning, which subsequently became the 'Ancient Identities' project (Bonacchi, Hingley and Yarrow, 2016). This project-which also involves my colleagues Chiara Bonacchi, Tom Yarrow and Kate Sharpe-explores the uses of ideas drawn from the Iron Age and Roman past by stakeholders across England, Scotland and Wales. ${ }^{3}$ It also seeks to set these examples in a broader international context. It marks the end of a transition in my work which started with a focus on the uses of 'Images of Rome' in the Victorian and Edwardian past and this has now shifted to an agenda that addresses the reception of the Iron Age and Roman past in the present. The link with Funari and his co-workers here is quite direct, since their research has helped to inspire my changing focus.

\section{Transforming agendas}

One of the key texts that we used in the development of the 'Ancient Identities' project was Pedro Funari and Renata Garraffoni's 'The Uses of Roman Heritage in Brazil' (Garraffoni and Funari, 2012). This is one of the few works that I have found that explicitly addresses the current relevance of Roman heritage, a topic that is largely absent from the theoretical field of study on Roman archaeology in Britain. In Brazil, a critical approach has developed over the past decade and a half that focusses upon the use of Roman heritage in academic scholarship and popular culture (ibid., 53). This research has explored the relationship between heritage, modern identity and concepts and materials defined from the Roman past in order to address Brazil's place in western culture. Although there are some connections between the research that has developed in Brazil and the post-colonial Roman archeologies that have been developing in Britain (Garraffoni, Funari and Pinto, 2010), the agenda in Brazil has developed along a different trajectory and is rather

\footnotetext{
${ }^{3}$ It is funded by the Arts and Humanities Research Council and is running from 2016 to 2019 .
} 
more closely linked to the arguments and debates that developed within the World Archaeology Congress during the late 1990s.

Funari's own research has addressed the colonial and national context in which classical models and ideas have been received in Brazil. This work developed alongside the critique of Romanization that arose in England. Funari has explored the close connections between colonialism and the oppressive forms of government that existed in Brazil prior to the mid 1980s (Ferreira and Funari, 2015), addressing how classical culture was adopted and manipulated during Brazil's colonial period, including the use of Rome as a model for the Brazilian Empire (Garraffoni and Funari 2012 , 58). The interrogation of these connections between modern and ancient history provides that reason that post-colonial theory was first introduced to archaeological study in Brazil (ibid., 66-7). A recent focus of attention addresses the significance of Roman heritage to people in the present, providing a field of study that has great value to the society that has evolved in Brazil since the dictatorship was replaced by democracy in 1985 (ibid, 71). This concern with the identities of contemporary people in Brazil has helped to stimulate my developing research on the use of 'Images of Rome' in the European present, leading to the 'Ancient Identities' project.

The Roman past is felt to have the potential in Brazil to help foster diversity and social justice. An example that is provided by Garraffoni and Funari (ibid., 68-70) involves models drawn from the archaeological study of Pompeii that are used as a comparator for social issues inherent in Brazilian society in the present, for example those that relate to the identities of ordinary people, diversity, gender relations and sexuality. Garraffoni and Funari (ibid, 70) argue that:

From a dialogue with European scholars who seek a less static interpretation of the Roman world, some Brazilian scholars have been noticing that archaeology permits the ... construction of theoretical and less excluding models. Such [a] political position is fundamental not only to challenge traditional academic approaches and modern reception of Roman past based upon power and excluded forms of national identities, but also to think about other forms of sensibilities and worldviews.

This adoption of post-colonial approaches in Roman archaeology moves beyond the deconstruction of colonialist and nationalist discourses, emphasising that interpretations of the past can work directly with the relevance of the past to societies and stakeholders in the present. This suggests that new research on the Roman Empire can be designed and communicated to stakeholders in order to draw comparisons and contrasts without loosing sight of the issues of power that are entangled 
through the complex relationships that link the past with the present (Hingley 2015a).

The most interesting current comparison with the work on social inclusion in Brazil is the research in the UK is that is addressing mobilities and diaspora in the Roman period (Eckardt et al., 2014; Eckardt and Müldner, 2016). The analysis of human bone using stable isotope analysis and aDNA (ancient DNA) is demonstrating the fairly large-scale migration into Britain of people living in some of the major urban centres, including London, York and Winchester. A consciously effort is being made by archaeologists and educators to use this material to argue that migration into Britain is not entirely a recent phenomenon. This forms part of an effort to make people more tolerant of their neighbours in an age that is typified by growing nationalism and racism. We believe that Iron Age and Roman Heritages have considerable potential to address sensibilities and worldviews and our 'Ancient Identities' project is pursuing this agenda (Hingley, Bonacchi and Sharpe forthcoming).

My greatest debt to Funari - in addition to his generosity and hospitality during my two visits to Brazil-has been that he has helped me to gradually realise the significance of heritage in the context of Roman archaeology. My trips to Brazil, discussions with Funari, together with the article that he written on Roman heritage, have directly stimulated me to take a deeper interest in the contemporary relevance of 'Images of Rome'. I am sincerely grateful for the opportunity that this paper has offered me to emphasise the importance of Pedro's academic leadership, his friendship and scholarship.

\section{Bibliography}

BONACCHI, C., R. HINGLEY and T. YARROW. 'Exploring Ancient Identities in Modern Britain', Archaeology International 19, 2016, 54-7. <http://doi.org/10.5334/ai.1909>.

CIPOLLA, C.N. and K.H. HAYES (eds). Rethinking Colonialism: Comparative Archaeological Approaches. Gainesville, Fl, University Press of Florida, 2015.

ECKHARDT, H. and G. MÜLDNER. Mobility, Migrations and Diasporas in Roman Britain', in M. MILLETT, L. REVELL and A. MOORE (eds) The Oxford Handbook of Roman Britain. Oxford, Oxford University Press, 2016, 203-223. 
ECKHARDT, H., G. MÜLDNER and M. LEWIS. 'People on the move in Roman Britain', World Archaeology 46(4), 2014, 534-550.

FERREIRA, L.M. and P.P. FUNARI. The Archaeology of Slavery Resistance in Ancient and Modern Times: An initial outlook from a Brazilian perspective', in C. CIPOLLA and K.H. HAYES (eds), 2015, 190209.

FUNARI, P.P. Dressel 20 inscriptions from Britain and the consumption of Spanish olive oil. Oxford, BAR British 250, 1996.

FUNARI, P.P., R. S. GARRAFFONI and B. LATIEN (eds). New Perspectives on the Ancient World: Modern Perceptions, Ancient Representations. Oxford, BAR International 1782, 2008.

FUNARI, P.P., M. HALL and S JONES (eds). Historical Archaeology: Back from the Edge. London, Routledge, 1999.

FUNARI, P.P., A. ZARANKIN and E. STOVEL (eds). Global Archaeological Theory: contextual voices and contemporary thoughts. New York/Boston, Kluwer, 2005.

GARRAFFONI, R. S. and P. P. FUNARI. 'The Uses of Roman Heritage in Brazil: Traditional Reception and new Critical Approaches,' Heritage $\mathcal{E}$ Society 5(1), 2012, 53-76.

GARRAFFONI, R.S., P.P. FUNARI and R. PINTO. 'O Estudo da Antiguidade no Brasil: as contribuiçōes das discussōes recentes', in R. HINGLEY, 2010, 9-25.

HINGLEY, R. 'The imperial context of Romano-British studies and proposals for a new understanding of social change', in P.P. FUNARI, M. HALL and S. JONES (eds), 1999, 137-49.

-- 'Medieval or Later Rural Settlement in Scotland: The Value of the Resource', in J. ATKINSON, I. BANKS and G. MacGREGOR (eds.) Townships to Farmstead: Rural Settlement Studies in England and Wales. BAR British Series 293, 2000a, 11-9.

-- Roman Officers and English Gentlemen. London: Routledge, 2000b.

-- (ed.). Images of Rome: Perceptions of ancient Rome in Europe and the United States of America in the modern age. Journal of Roman Archaeology, Supplementary Series no. 44, 2001. 
-- Concepçōes de Roma: uma perspectiva inglesa', in textos Didáticos: repensando o mundo antigo 47, 2002, 27-62.

-- Globalizing Roman Culture: Unity, Diversity, Empire. London, Routledge, 2005.

-- O Imperialismo Romano: novas perspectivas a partir da Bretanha. Butantã, Annablume, 2010.

-- Hadrian's Wall: A Life. Oxford, Oxford University Press, 2012.

-- 'Post-colonial and Global Rome: the genealogy of empire'. In M. PITTS and J. M. VERSLUYS (eds.) Globalisation and the Roman World: World History, Connectivity and Material Culture. Cambridge: Cambridge University Press, 2015a, 32-46.

-- 'Working with Descendant Communities in the Study of Roman Britain: Fragments of an Ethnographic Project Design'. In C.N. CIPOLLA and K.H. HAYES (eds.), 2015b, 161-89.

MATTINGLY, D. 'Dialogues of Power and Experience in the Roman Empire'. in D. MATTINGLY (ed.) Dialogues in Roman Imperialism: Power, discourse, and discrepant experiences in the Roman Empire. Portsmouth, Rhode Island, Journal of Roman Archaeology. No. 23, 1997, 7-25.

-- 'Being Roman: expressing identity in a provincial setting', Journal of Roman Archaeology 17, 2004, 5-25.

WEBSTER, J. 'Roman imperialism and the "post-imperial age"', in J. WEBSTER \& N. COOPER (eds) Roman Imperialism: Post-colonial perspectives. Leicester, School of Archaeological Studies, University of Leicester. No. 3, 1996, 1-18. 